\title{
Intermédialités
}

Histoire et théorie des arts, des lettres et des techniques

Intermediality

History and Theory of the Arts, Literature and Technologies

\section{Restitution Exhibitions: Issues of Ethnic Identity and Art}

\section{Reesa Greenberg}

Numéro 15, printemps 2010

exposer

displaying

URI : https://id.erudit.org/iderudit/044677ar

DOI : https://doi.org/10.7202/044677ar

Aller au sommaire du numéro

Éditeur(s)

Revue Intermédialités (Presses de l’Université de Montréal)

ISSN

1705-8546 (imprimé)

1920-3136 (numérique)

Découvrir la revue

Citer cet article

Greenberg, R. (2010). Restitution Exhibitions: Issues of Ethnic Identity and Art. Intermédialités / Intermediality, (15), 105-117. https://doi.org/10.7202/044677ar
Résumé de l'article

Ce texte se donne pour objet l'analyse des expositions de restitution d'art spolié aux Juifs pendant l'ère du national-socialisme postérieures à 2005 afin d'examiner les liens entre la propriété privée, les institutions publiques, et les présentations de musée. 


\title{
Restitution Exhibitions: \\ Issues of Ethnic Identity and Art
}

\author{
Reesa Greenberg
}

D estitution exhibitions are a new museum genre emerging after World War II in relation to the return of art and cultural property spoliated by the Nazi regime. The genre has expanded to include materials stolen by other cultures in other times and other places such as the 2010 displays in Rome and Palermo of the Morgantina treasure returned from the Metropolitan Museum in New York or artifacts from the Potlatch Collection from the holdings of the Canadian Museum of Civilization, the Royal Ontario Museum and the Museum of the American Indian now presented at the U'mista Cultural Society museum in Alert Bay, B.C. ${ }^{1}$ Regardless of chronology or typology, restitution exhibitions can comprise material that has been fully restituted, partially restituted or still sought. In such exhibitions the focus is on the act of restitution or the need for restitution rather than on aesthetic considerations, though these may be included. The majority of restitution exhibitions are temporary but as many more artifacts are returned, they are incorporated into permanent displays, either as individually identified items or as a designated permanent restitution exhibition. The new Acropolis Museum is a recent example of building an exhibition space in anticipation of restitution and permanent display.

The longevity, variety and particularity of restitution exhibitions pertaining to the Second World War merit closer study so as to differentiate restitution exhibitions pertaining to art stolen from Jews from other types of World War II restitution exhibitions and compare with versions created in other contexts. To that end, this essay looks only at restitution exhibitions related to stolen art believed or known to be owned by individual European Jews in the National Socialist era in order to examine complex questions and layered relationships

1. For the long history of the return of the Potlatch Collection, see www.umista.org/ collections/index.php (last access July 30, 2010). 
involving private property, public institutions and museum display. I begin with a brief summary of restitution exhibitions that occurred prior to the $60^{\text {th }}$ anniversaries of the Second World War. I then examine in greater detail the characteristics of post-2005 restitution exhibitions and offer some thoughts on why such exhibitions occur in such numbers as well as the roles they play in contemporary culture. $^{2}$

Pre-2005 Restitution Exhibitions: Spoliated Art and the State: in the decade after the Second World War in France and Holland, government sponsored restitution exhibitions were organized for two purposes: as triumphs celebrating the repatriation of cultural property and as instruments to facilitate re-uniting unclaimed stolen property with its rightful owner. These exhibitions served as markers of post-war, post-Nazi national justice and the restoration of national cultural patrimony. ${ }^{3}$

In 1997, when issues of restitution were being assessed once again by the French government, the MNR (Musées Nationaux Récupération) mounted a series of exhibitions of unclaimed art in the custody of various national museums that served as public demonstrations of the care "orphaned" works were given and as an aide to further restitution. The exhibition at the Centre Pompidou, Présentation des ouvres récupérées après la Seconde Guerre mondiale confiées à la garde du Musée national de l'art moderne, is notable as the first restitution exhibition to include research information in the exhibition itself (photographs of the backs of canvases showing stickers or stamps providing provenance information), the first to publish different language versions of the catalogue (French and English), the first to mount a website to document the exhibition and serve as a research tool (still active), ${ }^{4}$ and the first to devise an expressive décor to present

2. For images of the exhibitions, please consult the websites cited after each exhibition in the list below.

3. There were two French post-war restitution exhibitions: Les chefs-d'œuvre des collections françaises retrouvées en Allemagne par la commission de récupération artistique et les services alliés, at the Orangerie in Paris from June-November 1946 and, between 1950 and 1954, an exhibition at the Musée national du château de Compiègne. For a general discussion of French restitution policies, see Claire Andrieu, "Two Approaches to Compensation in France: Restitution and Reparation” in Martin Dean, Constantin Goschler and Philipp Ther (eds.), Robbery and Restitution: The Conflict over Jewish Property in Europe, New York, Berghahn Books, 2007, p. 134-154.

4. www.cnac-gp.fr/musee/mnr/index.htm and www.centrepompidou.fr/musee/mnr/ index.htm (last access July 30, 2010). 
the artworks (curved walls suggesting protection). It is notable, as well, for inspiring the first restitution exhibition at a Jewish museum: in 1998, in reconfigured form, the same works constituted one of the opening displays at the new Musée d'art et d'histoire du Judaisme in Paris. ${ }^{5}$

Post-2005 Restitution Exhibitions: Spoliated Art as Personal Property: since 2005, restitution exhibitions pertaining to art and artifacts looted or taken from Jews by forced sale during the National Socialist regime are markedly different from those that occurred before. What were single-venue, focused in purpose, single nation exhibitions have become itinerant, international exhibitions with many agendas. Most striking is the increase in number: examples have been mounted in Luxemburg, Amsterdam, Berlin, Vienna, Paris, Montreal, Jerusalem, Greenwich (CT), Los Angeles and New York. Some have travelled to Frankfurt, London, San Francisco, West Palm Beach and San Antonio and elsewhere (see table). The questions I wish to address with regard to this development are why are there still restitution exhibitions about World War II, spoliated, privately owned art and artifacts, why are there so many, how do they differ from earlier exhibitions, and what contemporary purpose or purposes do they serve? In answering these questions, I will call attention to various display modes and the use of new technologies in the context of exhibition practices.

5. For further discussion of French restitution exhibitions see my "From Wall to Web: Displaying Art Stolen from Jews by Hitler” in Anthony Kiendl (ed.), Obsession, Compulsion, Collection: On Objects, Display Culture and Interpretation, Banff, Banff Centre Press, 2004, p. 92-109. For further discussion of the on-site/online relationships of the Pompidou exhibition see my "Editing the Image: Two On-site/Online Exhibitions" in Mark A. Cheetham, Elizabeth Legge and Catherine M. Soussloff (eds.), Editing the Image: Strategies in the Production and Reception of the Visual (Conference on Editorial Problems), Toronto, University of Toronto Press, 2008, p. 153-164. For a general discussion of restitution periodisation in France, see Andrieu, 2007, p. 134-154. For a history of restitution exhibitions in the Netherlands, see Eelke Muller and Helen Schretlen, Betwist Bezit: De Stichting Nederlands Kunstbezit en de Teruggave van Roofkunst na 1945, Zwolle, Waanders, 2002 and Julie-Marthe Cohen, A Matter of Conscience? Legal and Moral Aspects of Dutch Restitution Policy or Restitution of Art in the Netherlands after 1945, but what about the Restitution of Jewish Ceremonial Objects, unpublished lecture given at the conference Jewish Cultural Treasures in Europe after the Holocaust: Restitution and Relocation, Jewish Museum, Berlin, 24 and 25 January 2009. 


\section{POST-2005 RESTITUTION EXHIBITIONS OF ART AND ARTIFACTS STOLEN FROM JEWS DURING THE SECOND WORLD WAR}

2005 Le Grand pillage: der nationalsozialistische Kunstraub im zweiten Weltkrieg Musée d'histoire de la ville de Luxembourg: www.moxxo.de/schaustelle/koenig+ebersbach.html

2006 Auktion 392: Reclaiming the Galerie Stern, Düsseldorf Faculty of Fine Arts Gallery, Concordia University, Montreal; Ben Uri Gallery, London; Max and Iris Stern Gallery, Hebrew University, Jerusalem; Leo Baeck Institute, New York: www.auktion392.com

Looted, but from Whom? Hollandsche Schouwburg: www.geroofdmaarvanwie.nl/en/index.html

Gustav Klimt: Five Paintings from the Collection of Ferdinand and Adèle Bloch-Bauer Los Angeles County Museum of Art: www.lacma.org/art/exhibition/klimt/index.aspx

2007-2008 Adele Comes to America Neue Galerie, New York: www.neuegalerie.org/exhibitions/gustav-klimt-the-ronald-s-lauder-and-serge-sabarskycollections

2008 Looking for Owners: Custody, Research, and Restitution of Art Stolen in France during World War II Israel Museum, Jerusalem: www.imj.org.il/exhibitions/2008/MNR/index.html Musée d'art et d'histoire du Judaïsme, Paris: www.mahj.org/en/3_expositions/expo_passe_detail.php?niv=4 6 ssniv=10 Gannee_ date $=2008$ Gexpo_id $=78$

Orphaned Art: Looted Art from the Holocaust in the Israel Museum CODART, Netherlands: www2.codart.nl/exhibitions/details/169o/

2008-2009 Looting and Restitution: Jewish-Owned Cultural Artifacts from 1933 to the Present

Jewish Museum, Berlin; Jewish Museum, Frankfurt: www.juedisches-museum-berlin.dewww.juedisches-museum-berlin.del raub-und-restitution-weiss/en/home.php

Recollecting: Raub und Restitution MAK, Vienna: www.mak.at/mysql/ausstellungen_show_page.php?a_id=801

2008-2010 Reclaimed: Paintings from the Collection of Jacques Goudstikker Bruce Museum, Greenwich, CT (travelled to The Jewish Museum, New York; McNay Art Museum, San Antonio; Norton Museum of Art, West Palm Beach; Contemporary Jewish Museum, San Francisco): www.thejewishmuseum.org/exhibitions/Goudstikker 


\section{PRE-CONDITIONS FOR A NEW WAVE OF RESTITUTION EXHIBITIONS}

Some of the seemingly obvious reasons for these exhibitions I see as preconditions rather than full explanations.

1. A new wave of restitutions and restitution activity: at the end of the 1990s, major obstacles to restitution were addressed by implementing harmonization structures in the areas of law and research. 44 governments signed the 1998 Washington Protocols, ratifying a set of common principles with regard to restitution, thereby creating an international framework rather than the previous sets of national laws that often worked against non-national claimants. The 1992 formation of the European Union as a co-operative body with increasingly harmonized economic laws and an entangled sense of history and justice laid the ground for an integrated approach to questions of restitution as did the dissolution of the former Soviet Union in 1989 and the post-Communist culture of private property. Open borders also facilitated access to formerly closed archives that could provide information on provenance and the 1999 founding of the online site, lootedart. com, was instrumental in demonstrating how the internet could be used to pool and track information about spoliated art. The result of these initiatives was a marked increase in the number of restitution demands and the resolution of high profile restitution cases. Restitutions and restitution activities, however, do not necessarily result in exhibitions.

2. A new wave of public awareness and interest via various media: restitution once a silent or private matter, is now news and has become part of common culture, to use Thomas Crow's phrase. ${ }^{6}$ Specialized and popular newspapers and magazines, as well as on air broadcasts regularly cover restitution related material, with high profile instances of restitution to heirs of Jewish victims given prominence and celebrity status. Popular books (Hector Feliciano's 1997 The Lost Museum: The Nazi Conspiracy to Steal the World's Greatest Works of Art) and films (The Rape of Europa: The Fate of Europe's Treasures in the Third Reich and the Second World War, 2007, based on Lynn H. Nicholas' 1994 book of the same title) also bring information and issues before non-invested audiences. Newsworthy and popularized events do not necessarily result in museum exhibitions.

6. Thomas Crow, Modern Art in the Common Culture, Princeton, Yale University Press, 1998 . 
3. A new wave of Holocaust Museums and Memorials: recently built, largescale Holocaust museums erected throughout Europe and North AmericaWashington (1993), London (2000), Vienna (2000), Budapest (2004), Paris (2005), Berlin (2005)-are a key component in materializing Holocaust memory as relevant to today's political cultures. According to Dan Diner, the Holocaust has become "a foundational event for European collective memory" and the source of "a canon of human rights and powerful convictions against genocide." $7 \mathrm{My}$ sense is that in North America, Holocaust museums serve as national symbols of human rights, championing and encouraging religious and racial tolerance. The primary Holocaust museum narrative in both Europe and North America recounts the history of Hitler's plans to annihilate the Jewish people. Occasionally, as at the new Yad Vashem, Jerusalem (2005), Israel's national Holocaust museum, a very small section of the permanent exhibition recounts the expropriation of Jewish communal and private property through a few photographs of the period, the display of looted religious artifacts and/or a reconstruction of a packing case filled with Judaica, To date, no Holocaust Museum has mounted an exhibition solely devoted to restituted artworks, spoliation of private property, or individual attempts at restitution.

4. A new wave of Jewish museums in Europe: since 1987 Jewish museums in Europe closed by the Nazis have reopened in major centers-Amsterdam (1987), Frankfurt (1988), Vienna (1995), Paris (1998), Berlin (2001). However the existence of Jewish museums does not necessarily result in restitution exhibitions. The Israel Museum, founded in 1965, has held unclaimed art and artifacts brought to Israel during the early 1950 s by the Jewish Restitution Successor Organization (JRSO) but it was only in 2008, as part of the country's $60^{\text {th }}$ anniversary activities and as a companion to a restitution exhibition sent from France, that the museum mounted Orphaned Art: Looted Art from the Holocaust. ${ }^{8}$ European Jewish museums, historically founded by secular Jews as ethnographic museums and one of the scenes of communal spoliation crimes by the National Socialists would seem to be a logical venue for restitution exhibitions, especially because such exhibitions fulfill their current need to remember the Holocaust as part of their mandate. There are many types of exhibitions that Jewish museums

7. Dan Diner, "World War II as a Foundational Event in Uniting Europe" in Dan Diner and Gotthard Wunberg (eds.), Restitution and Memory: Material Restoration in Europe, New York, Berghahn Books, 2007, p. 19.

8. The Israel Museum inherited the holdings of the Bezalel National Museum. 
can use to commemorate the Holocaust, however, so other conditions must be in place to mount restitution exhibitions. When attempting to ascertain the commonalities of post-2005 restitution exhibitions, it is important to remember that not all restitution exhibitions post-2005 were generated by Jewish museums: the emergence of so many Jewish museums, however, turns attention to considerations of Jews, art and museums.

5. Temporary exhibitions are the modus operandi of art museum practice: in the late $20^{\text {th }}$ century, museum culture shifted from an emphasis on the permanent collection to temporary exhibitions. The positive side of this development is the opportunity to rethink exhibition formats, topics, and perspectives. Permanent exhibitions often do not allow for the same degree of flexibility or experimentation, especially with sensitive subjects, and may not be able to address recent developments in a timely fashion. The negative side of so many temporary exhibitions is that they can become spectacles, even if they were not deliberately conceived as such. Despite the perceived need for innovative exhibition themes and the rise in popular exhibitions of "dark" or disreputable artworld practices such as forgery", restitution exhibitions with their appeal as solved or unsolved thefts or even their references to the spectacular aspects of National Socialist cultural and racial practices, are not a given.

6. Anniversaries of the end of World War II and the Founding of Israel: although the $60^{\text {th }}$ anniversaries of the end of the Second World War (2005) or the founding of Israel (2008) as a nation state provide opportunities for commemorative exhibitions, it is atypical that these are restitution exhibitions. Typically, exhibitions commemorating such occasions focus on the victory of the Allied forces or the struggle to create a Jewish homeland. Art museums might choose exhibitions of war art or propaganda or art made at the time of emerging statehood or use the opportunity for a survey of art made since the nation's founding, which, in fact, is what Israel did with Sixty Years of Art in Israel by holding six exhibitions, one devoted to each decade of Israel's art history, at six museums throughout the country. Restitution exhibitions used as memory devices for the end of a war or the beginning of a nation are a new phenomenon.

9. The Metropolitan Police Service's Investigation of Fakes and Forgeries, Victoria and Albert Museum, Saturday 23 January-21 February 2010; Close Examination: Fakes, Mistakes \& Discoveries, The National Gallery, London, 30 June-12 September 2010; Fakes, Forgeries and Mysteries, Detroit Institute of Art, November 21, 2010-March 10, 2011. 


\section{FEATURES OF POST-2005 RESTITUTION EXHIBITIONS}

If the pre-conditions only partially explain why, post-2005, there have been so many restitution exhibitions of cultural material spoliated in relation to World War II, a comparison with those that came before provides additional clues.

1. Spoliation of Jewish property is linked to the Holocaust: earlier exhibitions implied or alluded to Jews as victims. In $2 \mathbf{1}^{\text {st }}$ century restitution exhibitions, Jews are explicitly, and almost exclusively, identified as victims of looting, appropriation, aryanization, and forced sale, regardless of whether the exhibition is organized by or shown in an exclusively Jewish institution or whether the objects on display can with certainty be linked to Jewish owners. Unlike other forms of cultural spoliation in World War II, the specificity and extent of the spoliation of Jewish property is positioned as part of the Nazi genocidal enterprise that resulted in devastating, collective trauma.

2. The Grand Récit of Spoliation becomes Individual Stories: state narratives of cultural repatriation, custody and care, and efforts to identify owners for purposes of restitution are the dominant themes of $20^{\text {th }}$ century French restitution exhibitions. Attention was focused on the art on display. $21^{\text {st }}$ century restitution exhibitions may well include these themes but the emphasis shifts to stories of individuals: individuals involved in the looting, individuals who were looted or stolen from, individuals who attempt to reclaim spoliated property. There are now exhibitions devoted entirely or in part to the fate of dispossessed Jewish individual or family collectors (Bloch-Bauer), dealers (Jacques Goudstikker, Max Stern), and artists (Max Liebermann). Other exhibitions (Looted!: Current Questions Regarding the Cultural Looting by the National Socialists in Europe; Looting and Restitution; Recollecting: Raub und Restitution) include testimony, either print or video, from victims, heirs, and researchers. The trend of personalizing history through individual stories was first seen in war and ethnographic museums but is new in exhibitions devoted to stolen art. With $21^{\text {st }}$ century restitution exhibitions, the result is a shift from generic, impersonal accounts of looting and restitution to stories with named and visualized participants. Rather than focus solely on the objects of the crimes, victims are highlighted: ideally, personalizing Holocaust spoliation narratives fosters identification and sympathy. ${ }^{10}$

10. Visitor identification with Holocaust victims was introduced at the United State Holocaust Memorial Museum through issuing each visitor with a card bearing the name, photograph and biographical details of a Holocaust victim whose fate was learned only at 
3. Viewers are activated: $21^{\text {st }}$ century restitution exhibitions employ a variety of means to address and implicate viewers. These include using the interrogative (in titles or ancillary material) for purposes of interpolation (Paris, Berlin/ Frankfurt); placing computer stations in exhibitions to allow and promote individualized searches on looted art websites (Montreal, Jerusalem); creating online role playing games to highlight the ethical complexities of current restitution issues (Berlin/Frankfurt). Collapsing the distance between them (past victims of spoliation) and us (contemporary witnesses to or participants in restitution) fosters identification with and support for ongoing restitution processes.

4. Materialized Research: in addition to or in lieu of the contextualizing subjective, personal narratives in post-2005 restitution exhibition spaces, an objective framework or rationale for the exhibition is offered by including increasingly detailed accounts of looting processes, the fate of looted artworks, information on past and current restitution legislation, provenance research results, and the fate of restituted and non-restituted artwork. ${ }^{11}$ Restituted art is now given a context by including archival material in the form of documents, photographs or timelines. The practice of anchoring artworks is a current exhibition trend but in art exhibitions, the tendency is to focus on material that relates to the artist or to the process of creation or to the meaning of the work rather than on a framing, historical narrative detailing theft and restitution. Visually, research-on-display in pre-2005 restitution exhibitions was small-scale, discrete in size and quantity, whereas post-2005 research-on-display is often wall-size, overwhelming the space, extensive and copious. Earlier research-on-display focused on questions of provenance: post-2005 restitution exhibition research-on-display expands to include factual information on processes, procedures and personages, including transparency about the role of museums, art galleries, auction houses and post-war

the end of the visit. See Andrea Liss "The Identity Card Project and the Tower of Faces at the United States Holocaust Memorial Museum” in her Trespassing Through Shadows: Memory, Photography and the Holocaust, Minneapolis, University of Minnesota Press, 1998, p.13 et $s q$.

11. Here for example, is an excerpt from a press release typical of the stance: "The Jewish Museum Berlin would like to illustrate with this historical, documentational exhibition 'Looting and Restitution. Jewish-Owned Cultural Artifacts from 1933 to the Present' why so many restitution questions remain unsettled. The Museum thus aims to contribute to the objectification of the debate..." Press Release for The Special Exhibition Looting and Restitution: Jewish-Owned Cultural Artifacts from 1933 to the Present, Jewish Museum, Berlin, August, 2008, p. 6. 
governments in dispossessing Jewish owners. For example, after exhibition galleries devoted to the personal and professional life of Jacques Goudstikker, his role in creating and fostering markets through exhibitions and publications, and the presentation of restituted works, the last room of the Goudstikker exhibition focused on issues of restitution and research with the panel, A collection looted, presenting the history of the collection and its return, extracts from Clemens Toussaint's catalogue essay, How to Find One Thousand Paintings, and a digitized, viewer manipulable copy of Goudstikker's black book inventory (exhibited in a vitrine earlier in the exhibition) that served as an invaluable tool in settling the restitution case with the Dutch government. Looting and Restitution surrounded the artworks placed in the centre of galleries with wall panels outlining what happened year by year with information about individual artworks in labels adjacent to each object. By contrast, Looking for Owners, unlike previous exhibitions organized from the holdings of the Musées Nationaux Récupération MNR, displayed only up-to-date research results on looting processes in labels and text panels. Personal or subjective accounts were not included at all and discussion of the artworks as art was available only on audioguide. In addition to what is on display as research in exhibition spaces, substantial catalogues and/or exhibition websites are now de rigueur.

5. More varied display modes: according to my 2004 analysis $^{12}$, restitution exhibitions in the $20^{\text {th }}$ century alternated between orderly single-row hangs of artworks that conveyed care and respect for artworks and disorderly, cramped salon hangs associated with storage, abandonment and worthlessness. After 2005, restitution exhibitions employ a wider variety of modes. There are expressive installations such as Looting and Restitution (Berlin/Frankfurt) which used shipping crates and cluttered spaces throughout to convey the disruption and displacement of looted $\mathrm{art}^{13}$ or Looted! where each of the nine rooms of the exhibition was designed to underscore the historical period (NS-like long red banners with a black question mark instead of a swastika hanging on the façade of the museum or a red walled room with a banquet table set with placemats made of reproductions of art stolen by the Nazis) or emotional qualities of events

12. Greenberg, 2004 .

13. The packing case display device derives from Vera Frenkel's well-known, 19941995, art installation, Body Missing. See www.verafrenkel.com (last access July 30, 2010) and Vera Frenkel, "Letter to A. and A.", Intermédialités, n 6 "Remédier", Autumn 2005 , p. $143-177$. 
(overturned chairs in the room devoted to looting or the coolness of the red and white room devoted to the NS record keeping of what was looted). Some restitution exhibitions are hybrid installations employing elements from Holocaust, History or War museums (the room of video testimony and mural scale period photographs at Looted!). Some restitution exhibitions are paired with related exhibitions to offer a multi-faceted or layered viewing experience. These range from twinning restitution exhibitions derived from different collections as occurred in Jerusalem at the Israel Museum in 2008 to pairing both programmatically and spatially as in the sonic and visual bleed in the last room of the Goudstikker exhibition at the Jewish Museum in New York from the contiguous and simultaneous exhibition, Danube Exodus: The Rippling Currents of the River, an installation by Péter Forgàcs and The Labyrinth Project, that presented the displacement of various peoples during the Second World War. Another version of pairing is to combine contemporary art related to restitution with historical exhibits: Recollecting: Raub und Restitution juxtaposed 14 recent works with the case studies that inspired them as a way of bridging past and present. ${ }^{14}$ All of these devices (expressive, hybrid, pairing) are used to expand, amplify and dramatize the meanings of restitution exhibitions, to provide emotional, intellectual and historical links beyond the art on display, and to collapse then and now.

\section{WHAT IS EXHIBITED AND WHY?}

Ostensibly, what is exhibited in these post-2005 restitution exhibitions are issues related to the restitution of spoliated property owned by Jews-its history, its successes, its problems. It could be argued, however, that what is on display, are various identity formations pertaining to Jews and art as they play out or are performed in the public sphere of the museum. These resonate differently depending on venue, geography, and audience. With regard to Jewish identity, what is on display is a Jewish secular, urban and urbane, bourgeois, assimilated identity structure, the non-Jewish Jew, that, on the one hand, counters, stereotypical images of pre-war, religious, poor, shtetl Jews so prevalent in the public imaginary and, on the other, functions as a link between pre and post Second World War Jewish participation in national, and transnational, secular, cultural practices. Restitution exhibitions implicitly work to "restore" Jews to full citizenship as cultural agents in pre-Holocaust Europe: they counter stereotypes of

14. The artists were Carola Dertnig, Ines Doujak, Arnold Dreyblatt, Maria Eichhorn, Vera Frenkel, Rainer Ganahl, Klub Zwei, Michaela Melián, Christian Philipp Müller, Lisl Ponger, Silke Schatz, Till Velten, Arye Wachsmuth/Sophie Lillie. 
Jews as a "nation without art" (to invoke the title of Margaret Olin's book ${ }^{15}$ ) by functioning as visual reminders of the important roles Jewish dealers, artists, and collectors played during modernity in establishing and determining the infrastructure of the artworld. Some restitution exhibitions or events such as the 2006 purchase and display of Gustav Klimt's Adèle Bloch-Bauer by Ronald Lauder, cofounder of the Neue Galerie in New York, for \$135 million from Maria Altman, Bloch-Bauer's heir, also invoke the powerful role that contemporary Jews play in shaping today's art and restitution worlds while skirting the edges of stereotypes of the wealthy Jew and Jews controlling culture. ${ }^{16}$ These negative stereotypes are fed by a growing history of Jewish heirs selling restituted spoliated artwork previously held in State collections (Holland/Austria) for very high prices and Jews who demand restitution of State held spoliated work being perceived as enemies of communal or universal culture. ${ }^{17}$

At the same time, restitution exhibitions also can be positioned as manifestations of the Jewish religious injunction zachor (to remember) ancestors, history, and, especially, the Holocaust, arguably the key determinant of post Second World War Jewish identity. Restitution exhibitions, then, are materialized memory, offering a different perspective on the deprivation, dehumanization and deaths associated with the Holocaust, not least of which is the reinsertion of individual identities and different narratives in what is often portrayed as a generic ethnic genocidal tragedy. In remembering, the accompanying implicit claim is to an identity formation of individuals integral to and integrated with cultural presence in past and contemporary histories.

But what of art and its post-2005 identity? Restitution scholars such as Constantin Goschler and Dan Diner make the link between renewed restitution, the rise of civil society, and the spread of a liberal, global economy predicated on private property, especially after the fall of the former Soviet Union. ${ }^{18}$ What is not

15. Margaret Rose Olin, The Nation without Art: Examining Modern Discourses on Jewish Art (Texts and Contexts), Lincoln, University of Nebraska Press, 2001.

16. Display of Klimt's painting was a condition of the sale. See Tyler Green, "This is Our Mona Lisa”, Fortune Magazine, September 28, 2006, money.cnn.com/magazines/ fortune/fortune_archive/2006/10/02/8387512/index.htm (last access July 30, 2010).

17. A condition of the sale to Lauder was permanent display, possibly in response to fears expressed by the Austrian government prior to restitution that the work would be lost to the public.

18. See Diner and Wunberg (eds.), 2007 and Constantin Goschler and Philipp Ther, "A History without Boundaries: The Robbery and Restitution of Jewish Property in Europe" in Dean, Goschler and Ther (eds.), 2007. 
discussed in these accounts is the changed status of art as a commodity during the same time period, its meteoric rise in monetary value, and its repositioning as a safer investment compared to stocks, bonds, mortgages, banks, or currencies. ${ }^{19}$ To ensure that art is a safe investment for the individual, it must be seen to be protected from state interference. So, while it could be argued that restitution exhibitions function as public demonstrations of justice, international as well as national, immediate as well as long-term; as manifestations of the effectiveness of changed policies and practices regarding cultural and personal property looted from Jews during World War II (new legislation, open archives, digitized records, digital communication, and persistent investigation/research), and as a proof for the value of continued pursuit of and research on lost or unrestituted objects, it can also be argued that what is on display is an assurance to presentday art investors, Jewish or not, that, even if their artwork is confiscated by the state or its agents, it will be returned, if only eventually. In other words, restitution exhibitions function as imprimatur, indenture, insurance for art as private property, private property that may be given to a museum but private property nonetheless. There is an assumption that once art has entered a museum, art's status as private property evaporates, that it is part of a common heritage, that it exists in a world of its own, a world with universal values. Monetary value is never discussed in a museum, nor is the monetary relationship between a museum's holdings and what is held in private hands. With the restitution exhibitions I have been discussing, museums walk a fine line between contextualizing art in communal, social and political histories and colluding in the commodification of art for today's market. It is precisely these links between private property, the market, and museums that differentiate restitution exhibitions of spoliated property stolen during the National Socialist regime from individual Jews from museum restitution exhibitions of expropriated communal property, Jewish or not. That said, one repercussion of the critical mass of recent personal property restitution exhibitions could well be a contribution to a climate of return for "other" stolen art and artifacts.

19. For a recent assessment of the art market, see the series of articles by Fiammetta Rocco and Sarah Thornton in The Economist, November 28, 2009, including "New or Secondhand: The Ins and Outs of Primary and Secondary Markets". 